NOTE

\title{
Aroclor 1254 affects growth and survival skills of Atlantic croaker Micropogonias undulatus larvae
}

\author{
Ian D. McCarthy ${ }^{1,2, *}$, Lee A. Fuiman ${ }^{1}$, Maria C. Alvarez ${ }^{1}$ \\ ${ }^{1}$ University of Texas at Austin, Marine Science Institute, 750 Channel View Drive, Port Aransas, Texas 78373, USA \\ ${ }^{2}$ Present address: School of Ocean Sciences, University of Wales-Bangor, Menai Bridge, Askew Street, Anglesey LL59 5AB, Wales
}

\begin{abstract}
The aim of this study was to evaluate the effect of environmentally realistic egg loadings of the polychlorinated biphenyl Aroclor 1254 on the subsequent growth and behavioural survival skills of Atlantic croaker Micropogonias undulatus larvae. Adult fish were given a dietary administration of 0 (control) or 0.4 (dosed) mg Aroclor $1254 \mathrm{~kg}^{-1}$ fish d $\mathrm{d}^{-1}$ for $2 \mathrm{wk}$ during the final stages of gonadal recrudescence. Fertilised eggs collected from control and dosed adults immediately after spawning contained 0 and $0.66 \mu \mathrm{g}$ Aroclor $1254 \mathrm{~g}^{-1}$ egg, respectively. Growth rate (increase in total length) of dosed larvae was significantly lower than that of control larvae between 2 and $13 \mathrm{~d}$ post-hatching, with dosed larvae showing a $4 \mathrm{~d}$ delay in attaining the same size as control larvae. Behavioural assays were conducted to evaluate survival skills of larvae on Days 5 (complete yolk absorption), 9 (complete oil globule absorption), and 13 (larva wholly dependent on exogenous food sources) post-hatching. Survival skills examined were potential foraging rate (routine swimming speed and activity) and the response to a startle (transient vibratory stimulus) stimulus. Routine swimming speed and activity were similar for control and dosed larvae. There was a significant dose $\times$ age interaction in the responses of the control and dosed larvae to a vibratory stimulus. The percentage of control larvae responding to the stimulus, and their average and maximum burst speeds, increased with age. In contrast, no such age-related response was found in the dosed larvae. The results indicate that environmentally realistic body burdens of Aroclor 1254 transfer to the eggs and larvae, reducing their growth rates and impairing their startle responses, possibly making the larvae more susceptible to predation.
\end{abstract}

KEY WORDS: Endocrine disrupting chemicals · Polychlorinated biphenyls $\cdot$ Atlantic croaker $\cdot$ Fish larvae $\cdot$ Swimming activity $\cdot$ Predator avoidance $\cdot$ Sublethal effects $\cdot$ Growth

Resale or republication not permitted without written consent of the publisher

There is increasing concern regarding the introduction of endocrine disrupting chemicals (EDCs) into the environment and the developmental effects that these compounds may have on wildlife and humans (Colborn et al. 1993, Kavlock et al. 1996). EDCs are chemi- cal compounds that can disturb the development of the endocrine system or affect the organs targeted by the endocrine system. These effects can be observed at any stage of the life cycle from embryogenesis through to maturity, and can result in developmental abnormalities or reproductive impairment (Colborn et al. 1993). Particular attention has focused on the presence of various EDCs in the aquatic environment, such as organochlorines, polychlorinated biphenyls (PCBs), polycyclic aromatic hydrocarbons and alkylphenols and their potential impacts on fishes (Monosson 1997, Sumpter et al. 1997, Matthiessen \& Sumpter 1998).

PCBs comprise one of the most widely used and globally distributed classes of EDCs (Rice \& O'Keefe 1995). PCBs were used in industry between 1930 and 1976; however, the US (the major global producer) banned their production in 1977 due to concerns over their persistence when released into the environment and their potentially hazardous health effects on wildlife and humans (Rice \& O'Keefe 1995). It is estimated that $70 \%$ of the world's production of PCBs are still in use or in stock and therefore it is likely that PCB contamination will continue to pose an environmental threat (Sumpter et al. 1997). Indeed, it is recognized that PCBs will remain in the environment over geological time (Hooper et al. 1990). PCBs are globally distributed, and are found predominantly in sediments in the aquatic environment. The most likely route of PCB exposure for wildlife in the aquatic environment is recognized to be via the food chain (Rice \& O'Keefe 1995). Due to their lipophilic nature, organochlorine compounds bioaccumulate with trophic level, and the bioconcentration factors above background levels for these compounds in fish are between 1000 and 100000 (Saito et al. 1992). In general, fish do not metabolise PCBs very well; however, the rate at which females eliminate PCBs from the body increases during ovulation as lipoprotein-bound PCBs are deposited into the 
eggs during vitellogenesis (Binder et al. 1984, Ungerer \& Thomas 1996). As Weis \& Weis (1989) highlight in their review of the effects of environmental pollutants on fish development, 'although this is an efficient way of depurating the toxicant, it puts the next generation at risk.'

Most studies of contaminants in larval fishes have focused on the more obvious effects of PCB exposure, such as mortality rates and morphological deformities (Hogan \& Braun 1975, von Westernhagen et al. 1981, Niimi 1983, Weis \& Weis 1989, Billson et al. 1998, Olsson et al. 1999). However, recent work has shown that the maternal transfer of sublethal body burdens of organochlorine contaminants can severely impair the ecological performance (or survival skills) of Atlantic croaker Micropogonias undulatus larvae (Faulk et al. 1999). Since predation and starvation are the main causes of mortality during the larval stage (Houde 2002), the survival skills of a fish larva can be defined as those behaviors that enable a larva to successfully evade predators and find food, with any impairment resulting in an increased risk of mortality. Faulk et al. (1999) reported that exposure of Atlantic croaker larvae to environmentally realistic levels of $o, p^{\prime}$-DDT through maternal transfer, from contaminated food to the egg, resulted in significant impairment of larval survival skills. In this study, we examine the effect of parental exposure to the PCB Aroclor 1254 through the diet, during gonadal recrudescence, on the survival skills of Atlantic croaker larvae. We demonstrate that maternally derived $\mathrm{PCBs}$, at environmentally realistic levels, significantly reduce the growth rate and escape responses of larvae, which may have important consequences for individual and population mortality rates.

Materials and methods. Fish husbandry: Atlantic croaker broodstock were collected by gill netting during their October/November 1999 spawning run through the Aransas Pass ship channel in Port Aransas, Texas, USA, and transferred to 94501 recirculating seawater tanks at the University of Texas Marine Science Institute. The fish were maintained under constant environmental conditions (12:12 h light:dark photoperiod $2^{\circ} 2^{\circ} \mathrm{C}_{i} 31 \mathrm{PSU}$ ) and fed a ration of $3 \%$ body weight $\mathrm{d}^{-1}$ of ground shrimp. On 22 December, during final gonadal recrudescence, 2 groups of adult croaker, each consisting of 8 males and 16 females of approximately $400 \mathrm{~g}$ body mass, were placed in $5000 \mathrm{l}$ recirculating seawater tanks. One tank was designated as the control group and continued to receive the same ration of ground shrimp. The second tank, designated as the dosed group, received a ration of $3 \%$ body weight $\mathrm{d}^{-1}$ of ground shrimp containing Aroclor 1254 at a daily dose of $0.4 \mathrm{mg}$ Aroclor $1254 \mathrm{~kg}^{-1}$ fish d $\mathrm{d}^{-1}$ (source: Chem Service). After $2 \mathrm{wk}$ on this diet, 2 female fish were removed from both treatment groups, injected with $20 \mu \mathrm{g} \mathrm{kg}^{-1}$ luteinising hormone releasing hormone analogue (LHRHa) to induce spawning, and placed in spawning tanks along with 2 spermiating male fish from the same treatment group. This process was repeated 3 to $12 \mathrm{~d}$ apart using 2 female and 2 male fish from both treatment groups. In total, 5 separate spawns were obtained for the control and dosed treatments between 6 January and 18 February 2000.

Eggs were collected within $8 \mathrm{~h}$ of fertilisation and bathed in $1 \mathrm{ppm}$ formalin for 40 min to prevent bacterial and fungal infections. Groups of 2000 larvae were hatched in a 201 cylindrical tank and transferred (minus the hatching waste) to a second $20 \mathrm{l}$ tank for ongrowing. Samples of eggs were frozen and stored at $-20^{\circ} \mathrm{C}$ until analysis of their Aroclor 1254 concentrations. To maintain water quality in the rearing tanks, 41 of seawater (filtered to $0.1 \mu \mathrm{m}$ and UV sterilised) were replaced in each tank on a daily basis. Larvae were reared under a constant photoperiod (12:12 h light:dark), temperature $\left(21.2 \pm 0.2^{\circ} \mathrm{C}\right)$ and salinity (32.0 \pm 0.8 PSU). Rotifers Brachionus plicatilis, enriched with algae Nannochloropsis oculata and Isochrysis galbana were fed to the larvae every day at a concentration of 10 rotifers $\mathrm{ml}^{-1}$.

Aroclor 1254 is lipophilic, binds to vitellogenin, and accumulates in the yolk and oil globule of developing oocytes in Atlantic croaker (Ungerer \& Thomas 1996). Larvae mobilise these PCB stores during yolk and oil absorption. At $21^{\circ} \mathrm{C}$ and 32 PSU, complete yolk and oil globule absorption occur around 5 and $9 \mathrm{~d}$ after hatching, respectively (Faulk et al. 1999). Therefore, 2 behavioural assays, routine swimming activity and response to a startle stimulus were performed (see below) on Days 5 (complete yolk absorption), 9 (complete oil globule absorption) and 13 (larva wholly dependent on exogenous food sources). Ten larvae were sampled from each tank on Days 2, 5, 9 and 13 post-hatching, and their total length measured (see below) to determine growth rates. Aroclor 1254 in the eggs was extracted as outlined in Ungerer \& Thomas (1996), with the modification that heptane was used as a solvent instead of acetonitrile, and analyzed by gas chromatography (Hewlett-Packard Model 5890 gas chromatograph) with electron capture detection (Miller et al. 1981).

Behavioural assays: A startle stimulus was produced by the 'tap' of an electronically controlled metal hammer (head diameter $5 \mathrm{~mm}, 110 \mathrm{~mm}$ long) hitting a metal post (265 mm length) $27 \mathrm{~mm}$ below its highest point. The system used in this study was the same as that used by Faulk et al. (1999). At the beginning of each trial, a clear plastic dish (54 mm diameter, approximate volume $12 \mathrm{ml}$ ) containing 20 larvae was placed on a white platform on top of the metal post and the hammer was placed $5 \mathrm{~mm}$ away from the post. After $5 \mathrm{~min}$ acclima- 
tion, the routine swimming activity of the larvae was recorded for $3 \mathrm{~min}$. Recordings were made using a Cohu infra-red sensitive video camera (model 33152000/0000) located directly above the dish and connected to a Panasonic video monitor and recorder (model AG-1960) in an adjacent room. After recording swimming activity, the hammer was triggered remotely. When the hammer touched the metal pole, an electrical circuit illuminated an infra-red light-emitting diode in the camera's field of view. The infra-red light marked the onset of the stimulus and was not visible to the larva. This protocol was repeated for 2 to 6 dishes of 20 larvae (depending on the availability of larvae) for both control and dosed larvae at each age.

Data analysis: For routine swimming activity, a $30 \mathrm{~s}$ time period was randomly selected from the $3 \mathrm{~min}$ of video available for each dish. Ten fish were randomly selected and analyzed for the percentage of time they were active, their rate of travel (total distance traveled divided by $30 \mathrm{~s}$ ) and their active swimming speed (rate of travel divided by percentage of time active). Activity measurements were made using a computerised event recorder and the distance traveled measured using a computerised video measurement system (Measurement TV, Data Crunch software). For larvae responding to the vibratory stimulus, the response latency (in s) was measured by counting the number of video fields $(0.0167 \mathrm{~s}$ each) between the initiation of the stimulus and the onset of the response. Mean burst speed of each responding larva $\left(\mathrm{mm} \mathrm{s}^{-1}\right)$ was calculated from the distance traveled $(\mathrm{mm})$ and the duration of the response (number of video fields $\times 0.0167 \mathrm{~s}$ ). Maximum burst speeds $\left(\mathrm{mm} \mathrm{s}^{-1}\right)$ were calculated as the maximum distance traveled in 1 video field during the response period (distance traveled during $0.0167 \mathrm{~s}$ ).

Statistical analysis: All data are presented as mean values $\pm 1 \mathrm{SD}$. All statistical tests were conducted using SYSTAT Version 8.03. Growth rates of control and dosed larvae were examined using an analysis of covariance (ANCOVA) with total length as the dependent variable and age as the covariate. Length data were log-transformed to meet the assumption of normality. All behavioural data were examined using a 2-way ANOVA, with treatment (control or dose) and age as independent variables and including a dose $\times$ age interaction. Proportional data (\% responding, $\%$ time active) were arcsine-transformed and swimming speed data log-transformed prior to statistical analyses. Differences present at the $5 \%$ level were considered significant. Following the ANCOVA, and where the ANOVA indicated a significant dose $\times$ age interaction, age-wise $(n=3)$ and length-wise $(n=2)$ comparisons were made using 2-sample Student's $t$-tests. For these post-hoc statistical comparisons, a Bonferroni correction was applied.
Results. Eggs: The concentration of Aroclor 1254 in the eggs of the dosed group was $3.2( \pm 2.6$, range 0.1 to 6.3) $\mu \mathrm{g} \mathrm{g}^{-1}$ eggs. The Aroclor 1254 concentration in the control eggs was below the detection limit of the gas chromatograph. The wet mass of a single, fully hydrated, fertilised Atlantic croaker egg is $204 \mu \mathrm{g}$ (Sabath 2001), thus the amount of Aroclor 1254 per egg in the dosed group was approximately $0.66( \pm 0.54$, range 0.02 to 1.29 ) $\mathrm{ng} \mathrm{egg}^{-1}$.

Growth: At 2 d post-hatching, larvae in the control and dosed groups were not different in total length $(\mathrm{p}=$ $0.32): 2.54( \pm 0.04$, range 2.49 to 2.59$) \mathrm{mm}$ for the control group and $2.56( \pm 0.03$, range 2.52 to 2.58$) \mathrm{mm}$ for the exposed group, respectively (Fig. 1). Both control and dosed larvae increased in size during the first $13 \mathrm{~d}$ post-hatching (Fig. 1). Growth rate of control larvae (0.013 $\left.\mathrm{mm} \mathrm{d}^{-1}\right)$ was significantly faster than that of dosed larvae $\left(0.008 \mathrm{~mm} \mathrm{~d}^{-1}\right.$ ) (ANCOVA, $\mathrm{p}=0.011$ ). Post-hoc pairwise comparisons indicated that control larvae were significantly larger than the exposed larvae on Days $9(p=0.009)$ and $13(p=0.0004)$. Dosed larvae on Days 9 and 13 were not different in length from control larvae on Days $5(\mathrm{p}=0.94)$ and $9(\mathrm{p}=$ $0.67)$, respectively. Since the rate of development in marine fish larvae is size-related rather than agerelated (Fuiman \& Higgs 1997), Atlantic croaker larvae exposed to Aroclor 1254 appeared to exhibit a 4 d delay in development (Fig. 1).

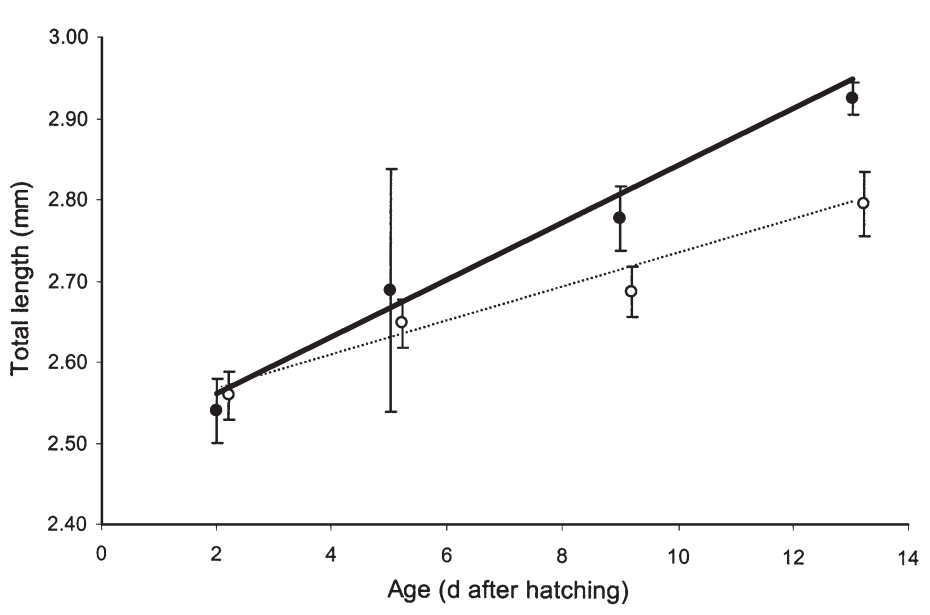

Fig. 1. Micropogonias undulatus. Growth of control and dosed Atlantic croaker larvae. Larvae came from eggs that contained 0 (control) and 3.2 (dosed) $\mu \mathrm{g}$ Aroclor $1254 \mathrm{~g}^{-1}$ eggs, respectively. Control and dosed larvae are represented by solid and open circles respectively, with the data for dosed larvae displaced by $+0.25 \mathrm{~d}$ for clarity. Growth curves were described by the following equations (TL = total length): control (solid line): $\ln (\mathrm{TL})=0.914( \pm 0.013)+0.013( \pm 0.002) \times$ age $\left(\mathrm{r}^{2}=0.767, \mathrm{p}<0.0001\right) ;$ dosed (dashed line): $\ln (\mathrm{TL})=0.927$ $( \pm 0.006)+0.008( \pm 0.001) \times$ age $\left(r^{2}=0.891, p<0.0001\right)$. Values are mean $\pm \mathrm{SD}$ 
Table 1. Micropogonias undulatus. Routine swimming activity in Atlantic croaker larvae at Days 5, 9 and 13 post-hatching $\left(21.2^{\circ} \mathrm{C}, 32.0 \mathrm{PSU}\right)$, parentally exposed to the polychlorinated biphenyl Aroclor 1254 at 0 (control) and 0.4 (dosed) mg Aroclor $1254 \mathrm{~kg}^{-1}$ fish d ${ }^{-1}$ through the diet. Aroclor 1254 concentrations in the eggs were 0 (control) and 3.2 (dosed) $\mu \mathrm{g} \mathrm{g} \mathrm{g}^{-1}$ eggs, respectively. Swimming activity data are means $( \pm \mathrm{SD})$ and include activity ( $\%$ time active), rate of travel $\left(\mathrm{mm} \mathrm{s}^{-1}\right)$, and active swimming speed (excluding periods of inactivity; $\mathrm{mm} \mathrm{s}^{-1}$ )

\begin{tabular}{|c|c|c|c|c|c|c|}
\hline \multirow{2}{*}{ Days post-hatching } & \multicolumn{2}{|c|}{$\%$ time active } & \multicolumn{2}{|c|}{ Rate of travel } & \multicolumn{2}{|c|}{ Active swimming speed } \\
\hline & Control & Dosed & Control & Dosed & Control & Dosed \\
\hline Day 5 & $5.00(1.06)$ & $3.50(0.99)$ & $0.45(0.30)$ & $0.49(0.13)$ & $9.31(5.83)$ & $14.52(2.23)$ \\
\hline Day 9 & $6.01(3.37)$ & $3.47(0.27)$ & $0.45(0.18)$ & $0.47(0.18)$ & $13.38(3.33)$ & $14.64(6.07)$ \\
\hline Day 13 & $4.22(2.25)$ & $3.51(1.50)$ & $0.67(0.14)$ & $0.46(0.14)$ & $18.57(6.41)$ & $14.95(6.55)$ \\
\hline
\end{tabular}

Routine activity: Atlantic croaker larvae were largely inactive and PCB treatment had no effect on the routine activity on Days 5, 9, and 13 post-hatching (Table 1). There was no effect of dose or age on the percentage of time that the larvae were active (dose, $\mathrm{p}=0.27$; age, $\mathrm{p}=0.74$ ) or their rate of travel (dose, $\mathrm{p}=$ 0.11 ; age, $p=0.50$ ) (Table 1 ). There was no effect of age on active swimming speed $(p=0.11)$, although there was a significant effect of dose $(p=0.046)$ and $a$ weak dose $\times$ age interaction $(p=0.08)$. Active swimming speed remained constant in the dosed larvae, but increased with age in the control larvae (Table 1).

Startle stimulus: The percentage of larvae responding to the vibratory stimulus was significantly different between the control and dosed larvae $(p=0.002)$. For the control larvae, responsiveness was low on Days 5 and 9 (ca. 15\%), but increased to $35 \%$ on Day 13 (Fig. 2a). In contrast, responsiveness of dosed larvae was low (ca. 15\%) for all days. There was a tendency for the latency between the presentation of the stimulus and the onset of the response to decrease with age ( $p=0.051$, Fig. 2b). However, there was no effect of PCB treatment on latency $(p=0.78)$. There was a significant effect of PCB exposure on both mean burst speed $(p=0.02)$ and maximum burst speed $(p=0.005)$ during the response to the startle stimulus (Fig. 2c,d). In control larvae, mean and maximum burst speed increased with age, whereas in the dosed larvae, mean and maximum burst speed showed little increase with age (Fig. 2c,d). Mean and maximum burst speeds of control larvae were significantly faster than the exposed larvae on Day 13 (mean burst, $p=0.007$; maximum burst, $p=0.005$ ). However, mean and maximum burst speeds of dosed larvae on Days 9 and 13 were not different from those of the control larvae on Days 5 (mean burst, $\mathrm{p}=0.09$; maximum burst, $\mathrm{p}=0.18$ ) and 9 $(\mathrm{p}=0.18 ; \mathrm{p}=0.12)$, respectively.

Discussion. There are few published data for PCB concentrations in marine fish eggs obtained by maternal transfer; most reported values are for ovarian tissue (e.g. Klauda et al. 1981, von Westernhagen et al. 1981, Johnson et al. 1992, Ungerer \& Thomas 1996). How- ever, Black et al. (1988) reported PCB loadings in eggs of winter flounder Pleuronectes americanus spawned from wild-caught females obtained from 3 sites in bays of Rhode Island and Massachusetts. Eggs from the 'clean' site had a loading of $0.2 \mu \mathrm{g} \mathrm{g}^{-1}$ egg, whereas eggs from the sites of 'low' and 'high' PCB contamination had loadings of 2.8 and $7.1 \mathrm{\mu g} \mathrm{g}^{-1}$ egg, respectively. Assuming a mean egg diameter of $0.8 \mathrm{~mm}$ (Bigelow \& Schroeder 1953) and a specific gravity of $1.090 \mathrm{~g} \mathrm{~cm}^{3}$ (Pearcy 1962, Smigielski \& Arnold 1972) for winter flounder, the mean weight of a winter flounder egg is approximately $292 \mu \mathrm{g}$. Therefore, the PCB concentrations reported by Black et al. (1988) represent loadings of $0.06,0.82$, and $2.07 \mathrm{ng} \mathrm{egg}^{-1}$ for the clean, low, and high PCB contamination sites, respectively. Thus, the average PCB loading in the croaker eggs of the present study is within the range of values reported by Black et al. (1988) and close to the values of their 'low' contamination site. Both Atlantic croaker and winter flounder feed as adults in estuaries. By comparison, species that live offshore, such as Atlantic mackerel Scomber scombrus, tend to have lower amounts of PCB in their eggs. Harding et al. (1997) reported mean levels of $133 \mathrm{ng} \mathrm{g}^{-1}$ of PCBs in mackerel eggs collected from St. Georges Bay in the southern Gulf of St. Lawrence. With a mean egg diameter of $1.3 \mathrm{~mm}$ (Ware 1977), and assuming the same specific gravity as winter flounder, the estimated egg weight is $1254 \mu \mathrm{g}$ and the mean PCB content for mackerel at this location is $0.17 \mathrm{ng} \mathrm{egg}^{-1}$. Egg survival through to hatching was not quantified in the present study. However, a parallel study using eggs obtained from the same experimental broodstock and the same doses of Aroclor 1254 indicated that hatching success (control $76 \%$, dosed $43 \%$ ) and survival of larvae $24 \mathrm{~h}$ (control $87 \%$, dosed $43 \%$ ) and $48 \mathrm{~h}$ (control $80 \%$, dosed $15 \%$ ) after hatching was lower in the eggs obtained from the PCB-exposed broodstock (P. Thomas unpubl. data). This is in agreement with the results of earlier studies in which parental exposure to PCBs reduced egg survival (von Westernhagen et al. 1981, Monod 1985, although see Matta et al. 2001). 

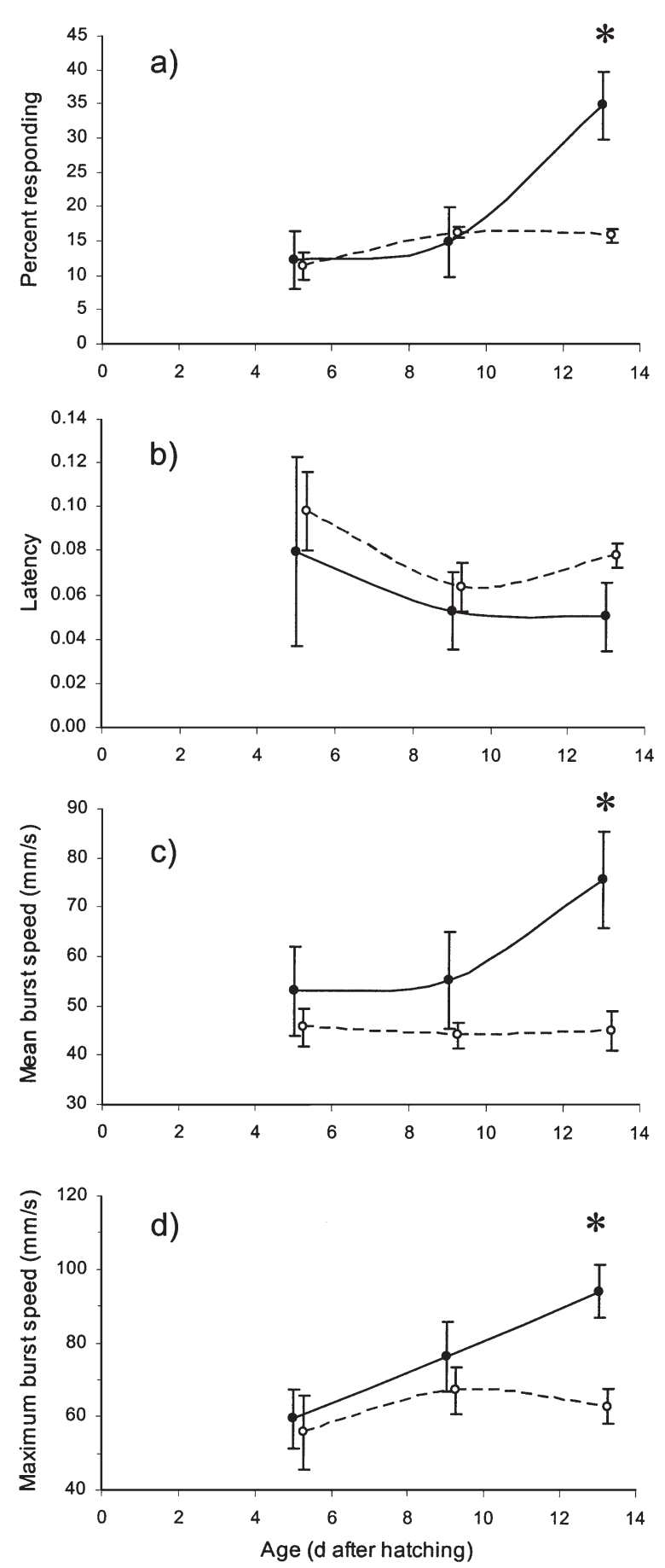

Fig. 2. Micropogonias undulatus. Responses of control and dosed Atlantic croaker larvae to a vibratory stimulus at Days 5, 9 and 13 post-hatching. Data are presented for (a) the responsiveness (\%), (b) response latency (s), (c) mean burst speed $\left(\mathrm{mm} \mathrm{s}^{-1}\right)$, and (d) maximum burst speed $\left(\mathrm{mm} \mathrm{s}^{-1}\right)$. Larvae came from eggs that contained 0 (control) and 3.2 (dosed) $\mu \mathrm{g}$ Aroclor $1254 \mathrm{~g}^{-1}$ eggs. Control and dosed larvae are represented by solid circles/solid line and open circles/dashed line, respectively, with the data for dosed larvae displaced by $+0.25 \mathrm{~d}$ for clarity. Significant differences between the control and dosed larvae at a given age are indicated by asterisks.

Values are mean $\pm \mathrm{SD}$
The effect of maternal exposure to organochlorine contaminants on growth rates in marine fish larvae has been little studied. In Atlantic croaker, maternal exposure to the organochlorines $o, p^{\prime}$-DDT or $p, p^{\prime}$-DDE had no effect on the subsequent growth rates of their larvae 2 to 21 d post-hatching (Faulk et al. 1999, Sabath 2001). Also, dietary exposure to PCBs for $20 \mathrm{~d}$ after yolk absorption did not affect the growth rate of striped bass Morone saxatilis larvae (Westin et al. 1983). However, in brook trout Salvelinus fontinalis, aqueous exposure to Aroclor 1254 for 10 d before hatching significantly reduced growth rates in exposed fry $48 \mathrm{~d}$ after hatching (Mauck et al. 1978).

The reduction in growth rate and apparent $4 \mathrm{~d}$ delay in the rate of development in PCB-exposed larvae in this study may have important ecological implications: specifically, increasing the duration of the larval period and the risk of predation mortality. Rapid growth is important for fish larvae, as predation mortality declines rapidly with increasing size (Petersen \& Wroblewski 1984). Fast-growing larvae have a smaller window of time during which they are highly vulnerable to predators, which results in lower cumulative mortality during the larval period. This is critical because a small change in mortality rate during the larval period can have a large impact on subsequent year-class strength (Houde 1987, 2002).

Exposure of Atlantic croaker larvae to sublethal levels of organochlorines (e.g. $o, p^{\prime}$-DDT and PCBs) via maternal transfer results in an impaired escape response to predatory stimuli (Faulk et al. 1999, this study). The proportion of Atlantic croaker larvae responding to a startle stimulus (Fig. 2a) was lower following a maternal dietary exposure to Aroclor 1254 compared to larvae derived from non-exposed broodstock. There was also an age-dependent decrease in latency with no differences between treated and control larvae (Fig. 2b). Similar latency results were reported by Faulk et al. (1999) for larvae derived from $o, p^{\prime}$-DDT-exposed broodstock. However, in contrast to the results of the present study, Faulk et al. (1999) observed no differences in the mean and maximum burst speeds between control and $o, p^{\prime}$-DDT-dosed larvae and no age-dependent increase in burst speeds as a response to a vibratory startle stimulus. However, $o, p^{\prime}$-DDT exposure significantly impaired burst responses to a visual startle stimulus, further confirming the deleterious effects of maternal transfer of sublethal levels of organochlorines on Atlantic croaker larvae.

The present study demonstrates that environmentally realistic loadings of a PCB (Aroclor 1254) in eggs of an estuarine fish, achieved through dietary exposure and maternal transfer, have significant effects on the survival potential of the larvae produced. Significant differences in growth rates between treated and 
control larvae delay development by about $4 \mathrm{~d}$. These changes in growth/development rates will prolong the larval period and increase larval stage mortality, which by itself could translate into a measurable effect on subsequent year-class strength. Moreover, dosed larvae exhibited fewer responses and poorer startle response performance at older ages, which should compromise their survival when attacked by predators. Taken together, these effects suggest that in their natural environment, larvae produced from adults residing and feeding in areas contaminated with Aroclor 1254 will exhibit greater vulnerability to predation, higher larval mortality, and possibly poorer recruitment.

Acknowledgements. We thank Dr. Peter Thomas and Dr. Izhar Khan for organising broodstock collection and for managing the dosing and spawning, Sonya Mathews for help with spawning and egg collections, Alyssa Braun for the GC analysis and Susan McBeath Lawson for her careful husbandry of the broodstock. This study was supported by a grant from the US Environmental Protection Agency (R-827399-010).

\section{LITERATURE CITED}

Bigelow HB, Schroeder WC (1953) Fishes of the Gulf of Maine. US Fish Wildl Serv Fish Bull 53:1-577

Billson K, Westerlund L, Tysklind M, Olsson PE (1998) Developmental disturbances caused by polychlorinated biphenyls in zebra fish (Brachydanio rerio). Mar Environ Res 46:461-464

Binder RL, Melancon MJ, Lech JJ (1984) Factors influencing the persistence and metabolism of chemicals in fish. Drug Metab Rev 15:697-724

Black DE, Phelps DK, Lapan RL (1988) The effect of inherited contamination on egg and larval winter flounder, Pseudopleuronectes americanus. Mar Environ Res 25:45-62

Colborn T, vom Saal FS, Soto AM (1993) Developmental effects of endocrine-disrupting chemicals in wildlife and humans. Environ Health Perspect 101:378-384

Faulk CK, Fuiman LA, Thomas P (1999) Parental exposure to ortho, para-dichlorodiphenyltrichloroethane impairs survival skills of Atlantic croaker (Micropogonias undulatus) larvae. Environ Toxicol Chem 18:254-262

Fuiman LA, Higgs DM (1997) Ontogeny, growth, and the recruitment process. In: Chambers RC, Trippel EA (eds) Early life history and recruitment in fish populations. Chapman \& Hall, London, p 225-249

Harding GC, LeBlanc RJ, Peter Vass W, Addison RF, Hargrave BT, Pearre S, Dupuis A, Brodie PF (1997) Bioaccumulation of polychlorinated biphenyls (PCBs) in the marine pelagic food web, based on a seasonal study in the southern Gulf of St. Lawrence, 1976-1977. Mar Chem 56 $(3-4): 145-179$

Hogan JW, Braun JL (1975) Abnormal rainbow trout fry from eggs containing high residues of a PCB (Aroclor 1242). Prog Fish-Cult 37:229-230

Hooper SW, Pettigrew CA, Sayler GS (1990) Ecological fate, effects and prospects for elimination of environmental polychlorinated biphenyls (PCBs). Environ Toxicol Chem 9:655-667
Houde ED (1987) Fish early life dynamics and recruitment variability. Am Fish Soc Symp 2:17-29

Houde ED (2002) Mortality. In: Fuiman LA, Werner RG (eds) Fishery science: the unique contributions of early life stages. Blackwell Science, Oxford, p 64-87

Johnson LL, Stein JE, Collier TK, Casillas E, McCain B, Varanasi U (1992) Bioindicators of contaminant exposure, liver pathology and reproductive development in prespawning female winter flounder (Pseudopleuronectes americanus) from urban and nonurban estuaries on the northeast Atlantic coast. NOAA Tech Mem NMFSNWFSC-1, NMFS, Seattle, WA

Kavlock RJ, Daston GP, DeRosa C, Fenner-Crisp P and 12 others (1996) Research needs for the risk assessment of health and environmental effects of endocrine disruptors: a report of the U.S. EPA sponsored workshop. Environ Health Perspect 104:715-740

Klauda RJ, Peck TH, Rice GK (1981) Accumulation of polychlorinated biphenyls in Atlantic tomcod (Microgadus tomcod) collected from the Hudson River, New York. Bull Environ Contam Toxicol 27:829-835

Matta MB, Linse J, Cairncross C, Francendase L, Kocan RM (2001) Reproductive and transgenerational effects of methylmercury or Aroclor 1268 on Fundulus heteroclitus. Environ Toxicol Chem 20:327-335

Matthiessen P, Sumpter JP (1998) Effects of estrogenic substances in the aquatic environment. In: Braunbeck $T$, Hinton DE, Streit B (eds) Fish ecotoxicology. Birkhäuser Verlag, Basel, p 321-335

Mauck WL, Mehrle PM, Mayer FL (1978) Effects of the polychlorinated biphenyl Aroclor 1254 on growth, survival and bone development in brook trout (Salvelinus fontinalis). Fish Res Board Can 35:1084-1088

Miller JD, Thomas RE, Schattenberg HJ III (1981) Determination of organochlorine pesticides and polychlorinated biphenyls in water by gas chromatography. Anal Chem 53:219-223

Monod G (1985) Egg mortality of Lake Geneva charr (Salvelinus alpinus L.) contaminated by PCB and DDT derivatives. Bull Environ Contam Toxicol 35:531-536

Monosson E (1997) Reproductive and developmental effects of contaminants in fish populations: establishing cause and effects. In: Rolland RM, Gibertson M, Peterson RE (eds) Chemically induced alteration in functional development and reproduction in fishes. Society for Environmental Toxicology and Chemistry (SETAC), Pensacola, FL, p 177-190

Niimi AG (1983) Biological and toxicological effects of environmental contaminants in fish and their eggs. Can J Fish Aquat Sci 40:306-312

Olsson PE, Westerlund L, The SJ, Billsson K and 5 others (1999) Effects of maternal exposure to estrogen and PCB on different life stages of zebra fish Danio rerio. Ambio (Stockholm) 28:100-106

Pearcy WG (1962) The ecology of an estuarine population of winter flounder, Pseudopleuronectes americanus (Walbaum). II. Distribution and dynamics of larvae. Bull Bingham Oceanogr Collect 18:16-38

Petersen I, Wroblewski JS (1984) Mortality rates of fishes in the pelagic ecosystem. Can J Fish Aquat Sci 41:1117-1120

Rice CP, O'Keefe P (1995) Sources, pathways, and effects of PCBs, dioxins and dibenzofurans. In: Hoffmann DL, Rattner B (eds) Handbook of ecotoxicology: contaminant sources and effects. Lewis Publishers, New York, p 424-468

Sabath DR (2001) Sublethal effects of maternal exposure to $p, p^{\prime}$-DDE on developing Atlantic croaker larvae (Micro- 
pogonias undulatus) at environmental concentrations. MSc thesis, University of Texas at Austin

Saito S, Tanoue A, Matsuo M (1992) Applicability of i/o-characters to a quantitative description of bioconcentration of organic chemicals in fish. Chemosphere 24:81-87

Smigielski AS, Arnold CR (1972) Separating and incubating winter flounder eggs. Prog Fish Cult 34:113

Sumpter J, Jobling S, Tyler CR (1997) Oestrogenic substances in the aquatic environment and their potential impact on animals, particularly fish. In: Taylor EW (ed) Toxicology of aquatic pollution. Society of Experimental Biology Seminar Series 57, Cambridge University Press, Cambridge, p 206-224

Ungerer J, Thomas P (1996) Transport and accumulation of

Editorial responsibility: Otto Kinne (Editor),

Oldendorf/Luhe, Germany organochlorines in the ovaries of Atlantic croaker (Micropogonias undulatus). Mar Environ Res 42:167-171

von Westernhagen $H$, Rosenthal H, Dethlefsen V, Ernst W, Harms U, Hansen PD (1981) Bioaccumulating substances and reproductive success in Baltic flounder Platichthys flesus. Aquat Toxicol 1:85-99

Ware DM (1977) Spawning time and egg size of Atlantic mackerel, Scomber scombrus, in relation to the plankton. J Fish Res Board Can 34(12):2308-2315

Weis JS, Weis P (1989) Effects of environmental pollutants on early fish development. Rev Aquat Sci 1:45-73

Westin DT, Olney CE, Rogers BA (1983) Effects of parental and dietary PCBs on survival, growth and body burdens of larval striped bass. Bull Environ Contam Toxicol 30:50-57

Submitted: August 12, 2002; Accepted: January 23, 2003

Proofs received from author(s): March 27, 2003 